\title{
延性接着剂を用いた接着継手の破壊靭性值 Fracture Toughness of Adhesive Joints Using Ductile Adhesive
}

\section{1.はじめに}

今日では，接着剤はさまざまな構造物に用いられるよう になってきたが, その際に大きな問題となるのが接着部の 脆性破壊である。延性接着剤は，そのような脆性破壊を防 ぐ目的で開発されたものである。延性接着剤を用いて接着 した接着継手の破壊靭性值は，そうで無いものに較へてて数 倍から十倍以上も高い值を示す。しかしながら，その破壊 靭性値は, ある程度より接着剤層厚みが薄くなると急激に 低下する傾向がある。また，急激に低下する前に特定の接 着剤層厚みで，破壊靱性值が最大值を示すすのもあるが， そのメカニズムを含めて依然不明な点が多い。本総説では, 接着継手に対する破壊力学の視点から見た破壊靭性值の接 着剂層厚さ依存性とそのメカニズムに対する著者の考え方 を解説する。

\section{2. 破壊力学を用いた接着強度試験}

破壊力学を用いた接着強度試験では，き裂の入った試験 片を用いる。この方法では, 試験結果を応力拡大係数やエ ネルギー解放率といった破壊力学パラメータで整理する。 これらの破壊力学パラメータは, 試験片の形状によらない ローカルな值であるため, より本質的なはく離強度を知る ことができるのが特徴である。

まず, き裂をむつ材料において, き裂が進展し, き裂面 積が単位面積だけ増加する際に解放されるポテンシャルエ ネルギーをエネルギー解放率 $G$ と呼ぶ ${ }^{11}$ 。

$$
G=-\frac{\partial U}{\partial A}=-\frac{1}{b} \frac{\partial U}{\partial a}
$$

ここで，Uは系のポテンシャルエネルギー, $A$ はき裂面

* 京都大学大学院工学研究科機械理工学専攻

京都市左京区吉田本町 $=606-8501$

Department of Mechanical Engineering and Science, Kyoto University

Yoshida Honmachi, Sakyo-ku, Kyoto, 606-8501 Japan
池田徹*・宮崎 則幸*

Toru IKEDA and Noriyuki MIYAZAKI

積, $b$ は板幅, $a$ はき裂長さである。また, エネルギー解 放率 $G$ は，コンプライアンス $C$ との間に次式の関係があ

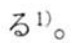

$$
G=\frac{F^{2}}{2 b} \frac{\partial C}{\partial a}
$$

ここで，Fはき裂をむつ板に作用する荷重を示す。よって， き裂をむつ板のコンプライアンス $C$ のき裂長さ $a$ による 変化を知ることができれば，エネルギー解放率を計算する ことが可能になる。

また,き裂に図 1 に示すようなモード I，II，IIIの荷重

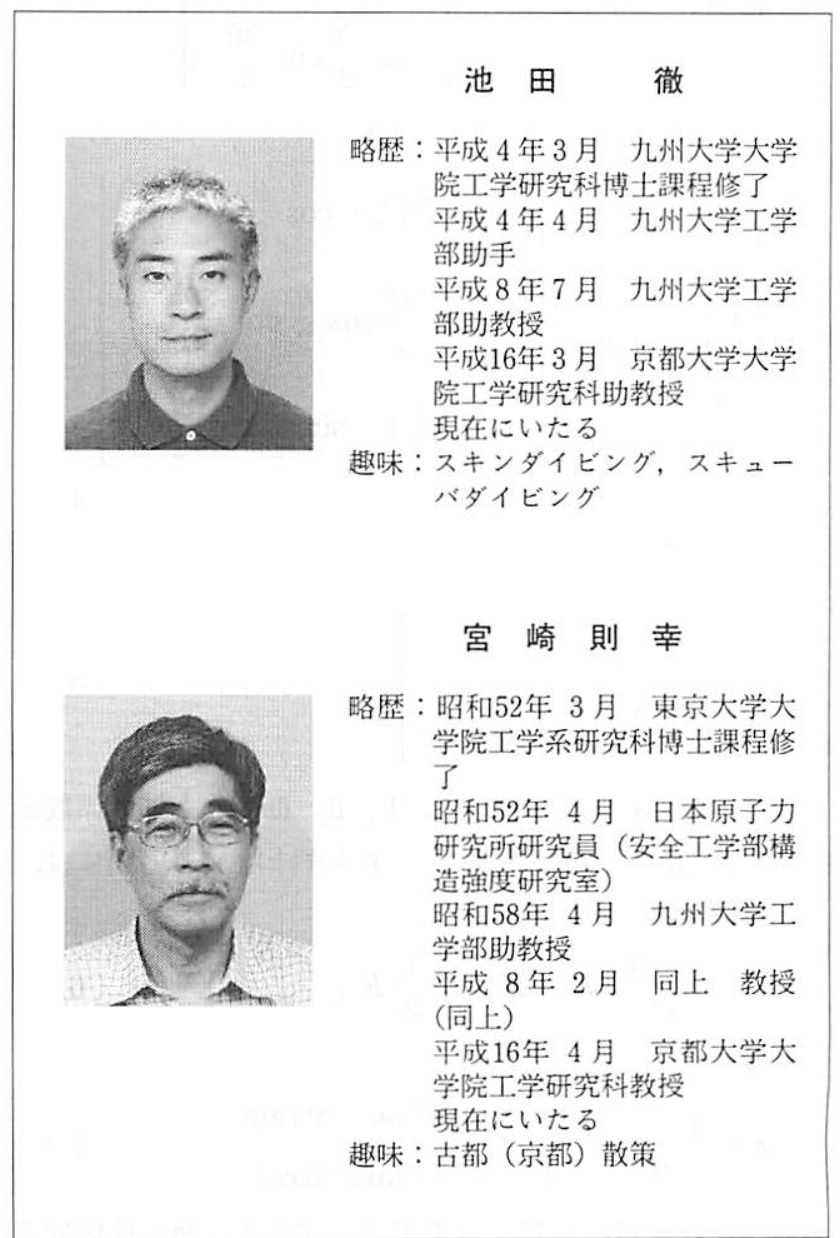




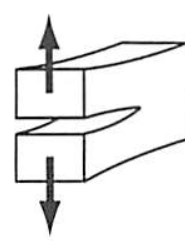

(a) モードI

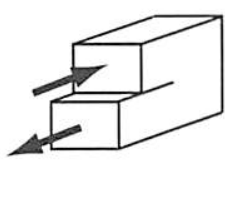

(b)モード II

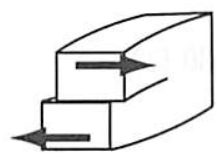

(c)モード III

図 1 き裂の開ロモード

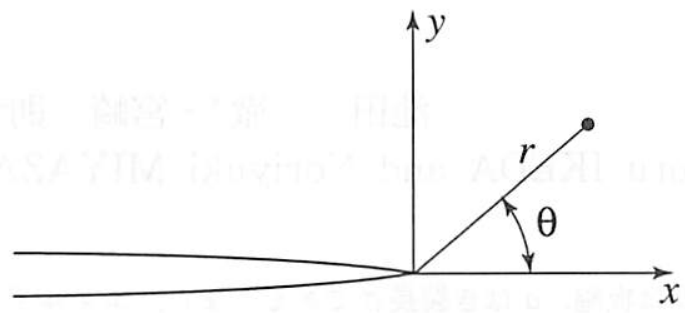

図 2 き裂先端の座標系

が負荷されたとき，図 2 に示すような座標系をき裂先端に とると, き裂先端近傍の応力場は, 次式で示される11。

(モ-ドI)

$$
\left\{\begin{array}{c}
\sigma_{x} \\
\sigma_{y} \\
\tau_{x y}
\end{array}\right\}=\frac{K_{1}}{\sqrt{2 \pi r}} \cos \frac{\theta}{2}\left\{\begin{array}{c}
1-\sin \frac{\theta}{2} \sin \frac{3 \theta}{2} \\
1+\sin \frac{\theta}{2} \sin \frac{3 \theta}{2} \\
\sin \frac{\theta}{2} \cos \frac{3 \theta}{2}
\end{array}\right\}
$$

(モードII )

$$
\left\{\begin{array}{c}
\sigma_{x} \\
\sigma_{y} \\
\tau_{x y}
\end{array}\right\}=\frac{K_{\mathrm{II}}}{\sqrt{2 \pi r}}\left\{\begin{array}{c}
-\sin \frac{\theta}{2}\left(2+\cos \frac{\theta}{2} \cos \frac{3 \theta}{2}\right) \\
\sin \frac{\theta}{2} \cos \frac{\theta}{2} \cos \frac{3 \theta}{2} \\
\cos \frac{\theta}{2}\left(1-\sin \frac{\theta}{2} \sin \frac{3 \theta}{2}\right)
\end{array}\right\}
$$

(モード III )

$$
\left\{\begin{array}{l}
\tau_{x z} \\
\tau_{y z}
\end{array}\right\}=\frac{K_{\mathrm{III}}}{\sqrt{2 \pi r}}\left\{\begin{array}{c}
-\sin \frac{\theta}{2} \\
\cos \frac{\theta}{2}
\end{array}\right\}
$$

ここで, $K_{\mathrm{l}}, K_{\mathrm{II}}, K_{\mathrm{III}}$ をモード I, II, III の応力拡大係数と 呼ぶ。また, 応力拡大係数とエネルギー解放率の間には, 次式の関係がある。

$$
G=\frac{\kappa+1}{8 \mu}\left(K_{1}^{2}+K_{\text {II }}^{2}\right)+\frac{1}{2 \mu} K_{\text {III }}^{2}
$$

ただし，

$$
\kappa=\left\{\begin{array}{cc}
3-4 \nu & \text { (Plane Strain) } \\
(3-\nu) /(1+\nu) & \text { (Plane Stress) }
\end{array}\right.
$$

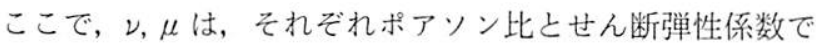

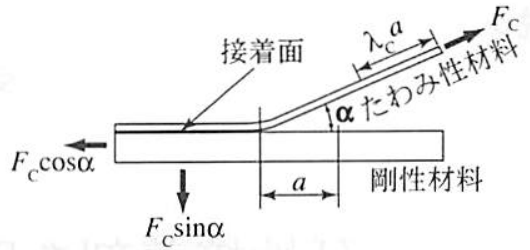

(a) ピール試験

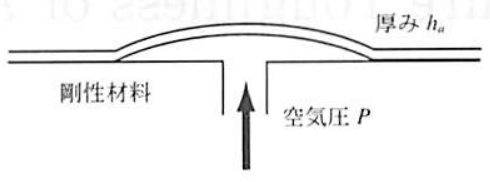

(b) ブリスター試験

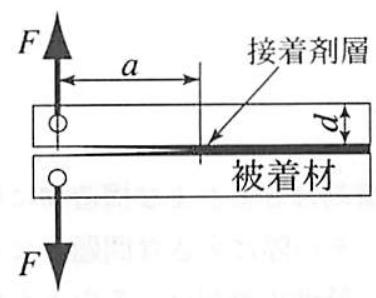

(c) ダブルカンチレバー(DCB)試験

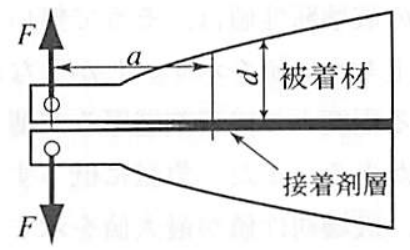

(d) 傾斜付 DCB(TDCB) 試験

図 3 き裂付接着試験法の例

ある。また，エネルギー解放率や応力拡大係数の破壊を生 じる臨界值を共に破壊䩲性值と呼び， $G_{\mathrm{C}}, K_{\mathrm{IC}}$ などのよう に記述する。

図 3 に示したものは，き裂付き接着試験法の例である。

(a) ピール試験

この試験方法は, 単なる機械的試験法としてあ用いられ るが，簡単にはく離荷重をエネルギー解放率に置き換える

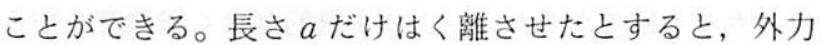
の仕事 $F_{\mathrm{C}} \lambda_{\mathrm{C}} a$ とはく離した部分に蓄えられたひずみエネ ルギー $a b h_{a} W$, き裂先端の左側への移動にともなう仕事 量 $F_{\mathrm{C}} a \cos \alpha$ とはく離に要されたェネルギー $G_{\mathrm{C}} a b$ が釣り 合うので, 次式が得られる2)。

$$
F_{\mathrm{C}} \lambda_{\mathrm{C}} a=a b h_{a} W+F_{\mathrm{C}} a \cos \alpha+G_{\mathrm{C}} a b
$$

ただし， $F_{\mathrm{C}}$ ははく離荷重， $\lambda_{\mathrm{C}}$ は伸び率， $b, h_{a}$ はたわみ性 材料の幅之厚さ, $\alpha$ は引張り角度である。よって, はく離 の際の破壊䩲性值は，次のように表せる。

$$
G_{\mathrm{C}}=\frac{F_{\mathrm{C}} \lambda_{\mathrm{C}}}{b}-\frac{F_{\mathrm{C}} \cos \alpha}{b}-h_{a} W
$$

あし，たわみ性材料にほとんよ゙伸びがなく， $\lambda_{\mathrm{c}} \approx 1.0$, $W \approx 0$ が成り立つならば, 式 $(9)$ は, 次のように簡単に 
なる。

$$
G_{\mathrm{C}}=\frac{F_{\mathrm{C}}}{b}(1-\cos \alpha)
$$

(b) ブリスター試験

剛体とみなせるジグの上に接着剤を塗布し，初期はく離 の半径を $a$ とするとき, 下方から空気圧 $P_{\mathrm{C}}$ を負荷したと きにはく離が進展したとする。接着風の厚さを $h_{a}$, ヤン グ率を $E_{a}$, ポアソン比を $\nu_{a}$ とするとき, そのエネルギー 解放率基準の破壊䩲性值 $G_{\mathrm{C}}$ は, 次式のように求められて (る3)。

$$
G_{\mathrm{C}}=\frac{1}{f\left(h_{a} / a\right)} \frac{P_{\mathrm{C}}^{2} a}{E_{a}}
$$

ただし, $f\left(h_{a} / a\right)$ は,

$$
f\left(\frac{h_{a}}{a}\right)=\frac{1}{1-\nu_{a}^{2}}\left[\frac{3}{32}\left\{\left(\frac{a}{h_{a}}\right)^{3}+\left(\frac{a}{h_{a}}\right) \frac{4}{1-\nu_{a}}\right\}+\frac{2}{\pi}\right]^{-1}
$$

接着剤の塗布厚さが, 初期はく離半径 $a$ よりも十分に小 さいとき, 式 (11)（12）は, 次式のように簡単になる。

$$
G_{\mathrm{C}}=\frac{3\left(1-\nu_{a}^{2}\right)}{32}\left(\frac{a}{h_{a}}\right)^{3} \frac{P_{\mathrm{C}}^{2} a}{E_{a}}
$$

(c) ダブルカンチレバービーム (DCB) 試験 接着剤の破壊勒性試験にしばしば用いられる試験で，エネ ルギー解放率 $G$ は, 古典材料力学の梁の曲げ理論より求 められる2)。

$$
G_{\mathrm{IC}}=\frac{4 F_{\mathrm{C}}^{2}}{b^{2} E_{\mathrm{S}}}\left(\frac{3 a^{2}}{d^{3}}+\frac{1}{d}\right)
$$

ここで， $F_{\mathrm{C}}$ は破壊荷重， $b$ は板幅， $E_{\mathrm{S}}$ は被着材のヤング 率, $d$ はビームの高さである。接着剤層が十分薄ければ基 本的にほとんどのひずみエネルギーがビーム部に蓄えられ るため, 接着㶡の厚みに依存しないのが特徴である。また, 負荷モードあ完全なモードI であるので, エネルギー解放 率基準の破壊勒性值も $G_{\mathrm{IC}}$ と記述した。

(d) 傾斜付き DCB (TDCB) 試験

上述の DCB 試験の梁の高さを徐々に変化させることで, エネルギー解放率が荷重のみから計算できる様に工夫した むのである。エネルギー解放率基準の破壊勒性值は, 次式 で示される2)。

$$
\begin{aligned}
& G_{\mathrm{IC}}=\frac{4 F_{\mathrm{C}}^{2} m_{b}}{b^{2} E_{\mathrm{S}}} \\
& m_{b}=\left(\frac{3 a^{2}}{d^{3}}+\frac{1}{d}\right)=\text { const. }
\end{aligned}
$$

\section{3. 応力拡大係数におよぼす接着剤層厚さの影響}

接着㓝層の厚みは, 一般に薄い方が接着強度が強いと考 えられているが，このことを破壊力学の観点から考えてみ たい。まず，図 4 に示すような剛体に挟まれた接着剤層を

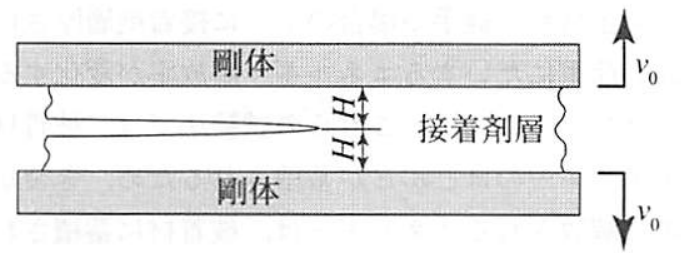

図 4 剛体に挟まれた接着剤層

考える。いま, 剛体と接着剤層の間は, 完全に固着してい ると考えると, 上下の剛体に強制変位 $\nu_{0}$ を与えたときの き裂の応力拡大係数は, 平面ひずみ状態の場合, 次式で与 えられる。

$$
\begin{aligned}
K_{1} & =\frac{E_{a}}{\left(1+\nu_{a}\right) \sqrt{1-2 \nu_{a}}} \frac{\nu_{0}}{\sqrt{H}} \\
& =\frac{E_{a}}{\left(1+\nu_{a}\right) \sqrt{1-2 \nu_{a}}} \varepsilon_{y} \sqrt{H}
\end{aligned}
$$

むし，突き合わせ継手ように遠方で一様応力を負荷する場 合, 接着剤層中のひずみ $\varepsilon_{y}$ は, 明らかに応力に比例する ため, 接着剤層中の微小き裂先端での応力拡大係数は同じ 荷重に対して $\sqrt{H}$ に比例して大きくなると考えられる。 言い換えると，もし同じ破壊䩲性值 $K_{\mathrm{IC}}$ において破壊が生 じるとすると, 破壊荷重は, $\sqrt{H}$ に反比例するように減 少するはずである。すなわち，突き合わせ継手において， 接着剤層厚さよりあ十分に長いき裂が欠宿として存在した 場合に, 予測される公称破壊応力は, 次式で表される。

$$
\sigma_{\mathrm{C}} \approx E_{a} \varepsilon_{y}=\frac{K_{\mathrm{IC}}(1+\nu) \sqrt{1-2 \nu}}{\sqrt{H}}
$$

この式に, 平均的なエポキシ樹脂の物性值, $K_{\mathrm{IC}}=0.5 \mathrm{MPa}$ $\sqrt{m} \approx 16 \mathrm{~N}(\mathrm{~mm})^{-3 / 2}, E_{a}=4000 \mathrm{~N} / \mathrm{mm}^{2}, \nu=0.4$ を代入し, 接着剤層の厚さの半分 $H$ に対して, 予測される破壊応力 をプロットしたのが図 5 である。このように, あし破壊勒 性值に接着剂層厚さ依存性が無ければ, 突き合わせ継手の 公称破壊応力は, 接着剤層が薄ければ薄いほど高くなる。 この意味では，接着剤層が薄い方が強度が上がると考えら れていることは，間違っていないのである。

しかしながら, 図 3 の DCB 試験片, TDCB 試験片など

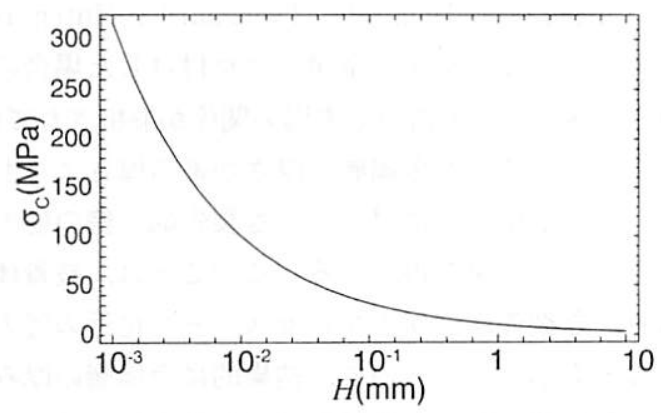

図 5 典型的なエポキシ樹脂を突き合わせ継手で接合した ときに推定される公称破壊応力 
では，突き合わせ継手の場合のように接着剤層厚さによっ て，同じ荷重にたいするエネルギー解放率が変化するとい うことはない。これは,これらの試験法では, 被着材にひ ずみエネルギーのほとんどが蓄積されるため, き裂が進展 する際に解放されるエネルギーは，被着材に蓄積されたひ ずみエネルギーがほとんどだからである゙)。

\section{4. 破壊勒性值におよぼす接着剤層厚さの影響}

前項において，接着剤の破壊勒性值が接着剤層厚みに対 して不変であれば, 突き合わせ継手の強度は，接着剤層が 薄いほど上昇すると述べた。しかしながら，延性的な性質 をむつ接着剤では, ある程度以上に接着剤層を薄くすると, 破壊靸性值そのものが低下することが知られている。接 着剂層の厚みによって破壊勒性值が変化する例として, Gardon ${ }^{5)}$ はピール試験において，接着剤層厚さが薄くな るほどピール強度（荷重が）小さくなることを見いだして いる。式 (10) より, ピール荷重と破壊䩲性值は比例する ため, 接着剤層が薄くなると破壊勒性值が低下したと言え る。Mostovoy と Ripling ${ }^{6)}$ は, 同様の滅少を TDCB 試験 によって見いだしている。Bascom ら 7.8) は, ゴム変成エ ポキシ樹脂について接着剤層厚さを变えた破壊勒性值の测 定を TDCB 試験片を用いて行い，厚い接着剂層から徐々 に接着剤層厚さを減じてゆくと, き裂先端塑性域代表寸法 $2 r_{\mathrm{p}}$ とほぼ同じ接着剤層厚さになるまで少しずつ破壊勒性 值が増大し，その後，さらに接着剤層厚さが薄くなると急 激に破壊勒性值が減少することを見いだしている。Irwin によって提案された有名なき裂先端塑性域代表寸法の第一 近似値は, 次式で示される。

$$
\left\{\begin{array}{cc}
r_{p}=\frac{1}{2 \pi} \frac{E_{a} G}{\sigma_{0}^{2}} & \text { Plane Stress } \\
r_{p}=\frac{1}{6 \pi} \frac{E_{a} G}{\sigma_{0}^{2}\left(1-\nu_{a}^{2}\right)} & \text { Plane Strain }
\end{array}\right.
$$

ここで，Gはエネルギー解放率， $E_{a}, \nu_{a}$ は接着剤のヤング 率之ポアソン比， $\sigma_{0}$ は接着剤の降伏応力である。また， 同様の実験は, Kinloch と Shaw ${ }^{9)}$ によっても確かめられ ている。

また, Varias ら ${ }^{10)}$, Hsia ら ${ }^{11)}$, Tvergaard と Hutchinson ${ }^{12)}$ によって, セラミックスを金属でロウ付けした場合の, 金 属の厚さとき裂先端近傍の応力場の関係が解析されている。 彼らによるといずれも金属層の厚さがある厚さよりも薄く なると, 同じ $J$ 積分值に対して, き裂先端近傍の応力場が 上昇するとする結果を得ている。このことは，被着体の拘 束により, き裂先端近傍のプロセスゾーン付近の応力が上 昇することを示しているので, 結果的に金属層の厚みがあ る程度よりも薄くなると破壊䩲性值が低下してゆくことを 示している。
表 1 被着材と接着剤の材料定数

\begin{tabular}{cccccc}
\hline Material & $\begin{array}{c}E \\
(\mathrm{GPa})\end{array}$ & $\nu$ & $\begin{array}{c}\sigma_{0} \\
(\mathrm{MPa})\end{array}$ & $\alpha$ & $n$ \\
\hline Mild Steel & 210 & 0.3 & & & \\
\hline Epoxy Resin & 2.7 & 0.4 & 68 & 0.2 & 4 \\
\hline$\frac{\varepsilon}{\varepsilon_{0}}=\frac{\sigma}{\sigma_{0}}+\sigma\left(\frac{\sigma}{\sigma_{0}}\right)^{n}, \varepsilon_{0}=\sigma_{0} / E$ & & &
\end{tabular}

そこで,ゴム変成エポキシ樹脂接着剤について, 接着剤 単体中のき裂と軟鋼の被着材に拘束された場合のき裂先端 近傍の応力場について, 単体のエポキシ樹脂の破壊䩲性值 $J_{\mathrm{C}}=2000(\mathrm{~N} / \mathrm{m})$ よりやや低い $J=1500(\mathrm{~N} / \mathrm{m})$ での分布を 調べてみた ${ }^{4)}$ 。実際の破壊勒性値よりもやや低いレベルの エネルギー解放率での応力分布を調べたのは, 破壊靯性值 にあまりにも近い応力状態を調べようとすると，き裂先端 付近での変形が大きくなりすぎて, 大変形解析での計算が 収束できなくなるからである。解析は, 表 1 の物性值を 用いて，市販の FEM コードである MARC を用いて， Update Lagrange 法で大変形弾塑性解析を行った。 TCDB 試験片と Edge Cacked Plate Adhesive Joint under Uniform Tension (ECP) 試験片の FEM モデルを作成し, $J=1500(\mathrm{~N} / \mathrm{m})$ でのき裂先端付近での三軸引張り応力 $\sigma_{\mathrm{H}}$ を解析した結果を図 6 に示す。この図より， $\sigma_{\mathrm{H}}$ が接着剤 層厚さが薄くなると上昇していることがわかる。ゴム変成 エポキシ樹脂のプロセスゾーンはき裂先端の白化域の数分 の 1 はあると考えると, 少なくとあ $50 \mu \mathrm{m}$ 以上はあると 思われる。そこで, き裂先端から $50 \mu \mathrm{m}$ での三軸引張り 応力 $\sigma_{\mathrm{H}}$ の接着剤層厚さによる変化を図 7 に示す。これよ り，接着剤層厚さが $0.5 \mathrm{~mm}$ 程度になると急に $\sigma_{\mathrm{H}}$ の值が 増大していることがわかる。このことは, 接着剤層が薄く なるとある厚さよりあ薄くなった際に急速に破壊䩚性值が 減少してゆくことを示している。これは, 前述の Gardon ${ }^{5)}$ の試験結果や Mostovoy と Ripling ${ }^{6)}$ の実験結果の一部を 定性的に示している。また，セラミックスを金属で接合し た際の接合強度をシミュレーションした, Varias ら ${ }^{10)}$, Hsia ら ${ }^{11)}$, Tvergaard と Hutchinson ${ }^{12)} ら の$ 結果とあ良

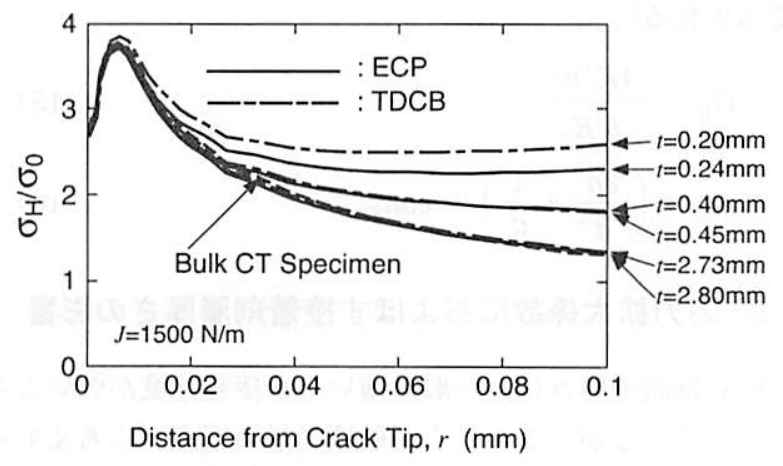

図 $6 \sigma_{\mathrm{H}}$ のき裂先端近傍での分布 


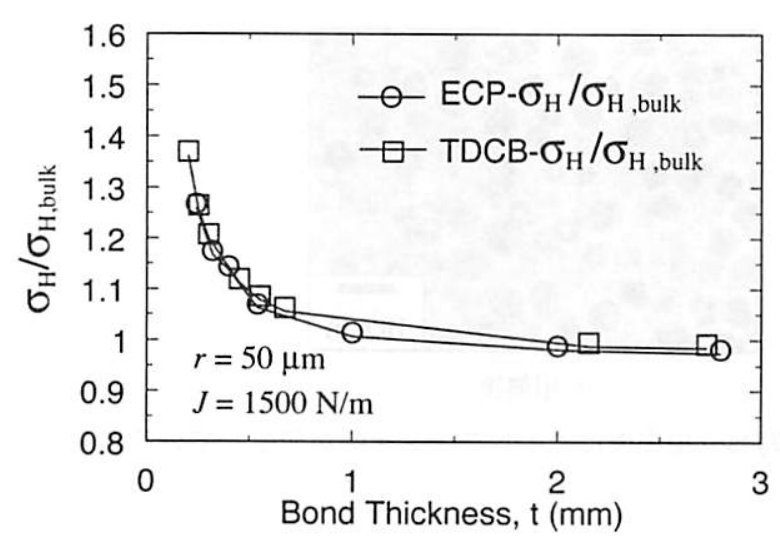

図 7 き裂先端加ら $50 \mu \mathrm{m}$ における $\sigma_{\mathrm{H}}$ の接着剤層厚さ による変化

く一致している。

しかしながら,ゴム変成エポキシ樹脂について実験を行っ た, Bascom ら ${ }^{7,8)}$ やKinloch と Shaw ${ }^{9)}$ の実験結果のよ うに, ある接着剤層厚さで, 破壊勒性值が極大值をとる理 由は, 説明できない。

\section{5. 接着剤層中のき裂先端近傍のダメージゾーンの 観察 ${ }^{13) 14}$}

そこで, 実際に厚みの異なる接着剤層内のき裂先端損傷 域を観察した。ここで用いたゴム变成エポキシ樹脂は, マ トリックス材に液体エポキシ樹脂（AER250, 長瀬チバ), 液状ブタジェンゴムに CTBN (CTBN1300×8, 宇部興産), 硬化剤に芳香族アミン（HY956，長瀬チバ）を用い，そ れぞれ， 83.3wt\%，12.5wt\%，4.2wt\%の割合で混合した ものである。これを $120^{\circ} \mathrm{Cで} 16$ 時間加熱して硬化させた。 接着継手は，接着面をシアンカップリング剤 $\left(\mathrm{C}_{9} \mathrm{H}_{20} \mathrm{O}_{5} \mathrm{Si}\right)$ で処理したアルミニウム（A6061）をこのゴム変成接着剤 で接着させることにより, 接着剤層厚みが $0.1 \mathrm{~mm}, 0.3 \mathrm{~mm}$, $0.7 \mathrm{~mm}, 1.5 \mathrm{~mm}, 2.1 \mathrm{~mm}$ の図 8 に示すような CT 型接着継 手破壊試験片を作成した。接着剤層中のき裂先端には，接 着剂の硬化前にあらかじめ厚さ $0.1 \mathrm{~mm}$ のカミソリ刃を挿入

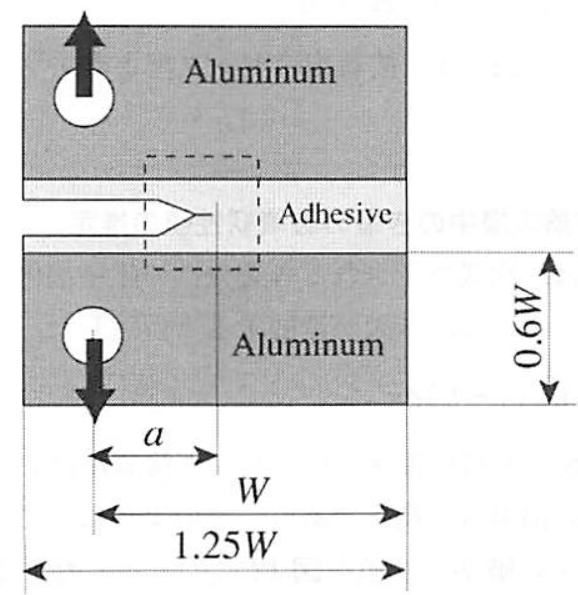

図 8 Compact Tension (CT) adhesive 試験片 ( $\mathrm{W}=48 \mathrm{~mm}$, thickness $=8 \mathrm{~mm}, \mathrm{a} / \mathrm{W}=0.5)$.
しておき，硬化後に抜き取った。この様にして得られた試 験片の破壊䩲性值を図 9 に示す。これより, Bascom ら 7,8$)$ や Kinloch と $\mathrm{Shaw}^{9)}$ の実験結果と同様に, $0.3 \mathrm{~mm}$ 程度 の接着剤層厚さで, 破壊勒性值が極大となっていることが わかる。また，それぞれの接着剤層厚さの試験片について， 平均破壊荷重の $95 \%$ の荷重を負荷した後に除荷した。こ れらの試験片のき裂先端部付近を低速切断機で切り出し, プレパラート上に貼り付けて厚さ $100 \mu \mathrm{m}$ に薄片化し，き 裂先端付近のゴム变成エポキシ樹脂の損傷状態を光学顕微 鏡により観察した結果の一部を図 10 に示す。

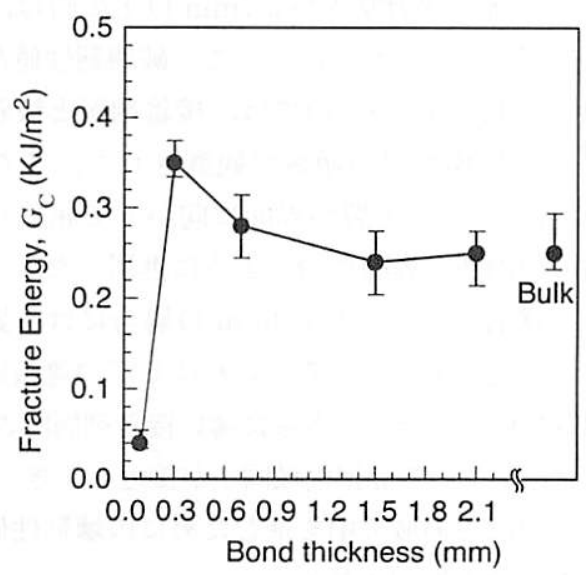

図 9 ゴム変成エポキシ樹脂における接着剤層厚さと 破壊靬性值の関係

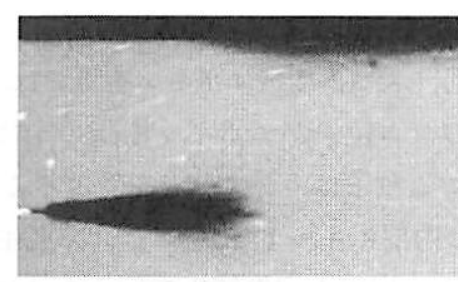

(a) 接着剤層厚さ $1.5 \mathrm{~mm}$ のケース

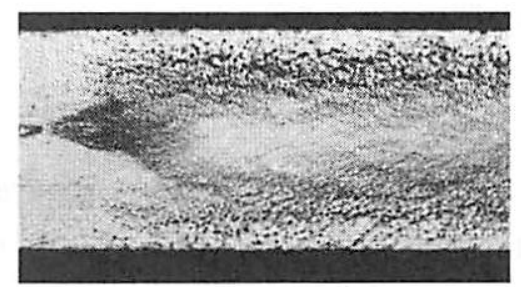

(b) 接着剤層厚さ $0.3 \mathrm{~mm}$ のケース

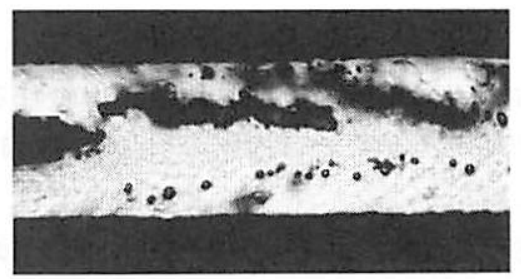

(c) 接着剂層厚さ $0.1 \mathrm{~mm}$ のケース

図 10 さまざまな接着剤層厚さによるき裂先端付近の ダメージゾーンの変化 


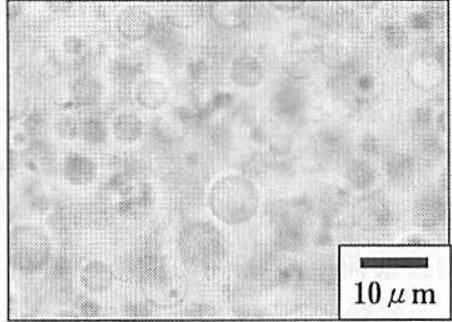

(a)損傷前

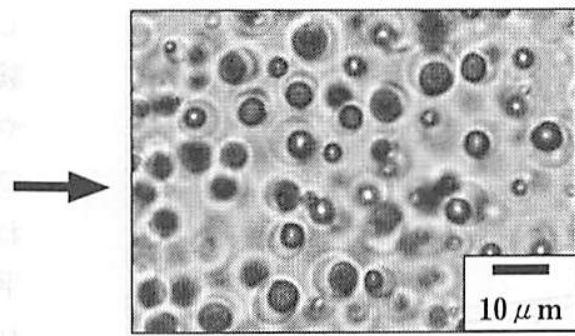

(b)損傷後

図 11 損傷を受ける前後のゴム変成エポキシ樹脂の顕微鏡写真（損傷後にキャビテーションが発生している）。

これより，接着剤層厚さが $0.7 \mathrm{~mm}$ 以上の時は，ほぼ同 じき裂先端損傷を呈したのに対して，破壊勒性值が極大值 を示した厚さ $0.3 \mathrm{~mm}$ のものでは，接着剤層と被着材の界 面に沿って大規模な損傷領域が観察された。また，厚さ $0.1 \mathrm{~mm}$ のものでは, き裂が界面に向かって屈曲し，この 界面損傷域の内部を界面に沿うように進展した。これらの 結果より，接着剤層厚さが $0.3 \mathrm{~mm}$ の場合には，界面損傷 がき裂先端の応力を低減する，いわゆる応力遮蔽効果のた めに破壊勒性值が上昇し，さらに薄い接着剤層厚さ $0.1 \mathrm{~mm}$ の場合には，上下の界面損傷域同士が接近しすぎ，き裂は， いずれかの界面損傷域の中を進むために破壊靱性值は急激 に低下したものと推測される。

\section{6. 有限要素法による損傷解析 ${ }^{15}$}

\section{1 損傷解析モデル}

本研究で使用したゴム変成エポキシ樹脂では, 直径 $5 \mu \mathrm{m}$ から $10 \mu \mathrm{m}$ のゴム粒子がエポキシ樹脂の中に分散してい る。これらのゴム粒子は, ダメージを受けることによって, 図 11 のように内部にキャビテーションを発生する。この ゴム变成エポキシ樹脂の損傷解析を行うために多孔質材料 の降伏モデルである，Gursonモデルを用いた。Gurson モデルの降伏関数は次式で示される。

$$
F=\left(\frac{\bar{\sigma}}{\sigma_{0}}\right)^{2}+2 f \cosh \left(\frac{\sigma_{k k}}{2 \sigma_{0}}\right)-1-f^{2}=0
$$

ここで, $\bar{\sigma}$ は Mises 応力, $f$ は粒子の体積含有率（ボイド 率),$\sigma_{k k} / 3$ は膨張応力, $\sigma_{0}$ は定数である。また, 体積含 有率は, 次式の様に変化する。

$$
\begin{aligned}
& \dot{f}=\dot{f}_{\text {growth }}+\dot{f}_{\text {nucleation }} \\
& \dot{f}_{\text {growth }}=(1-f) \dot{\varepsilon}_{k k}^{p}
\end{aligned}
$$

本解析では， $\sigma_{0}$ に樹脂の圧縮試験から得られる降伏応力 を用い, 初期ボイド率 $f_{0}$ は樹脂の引張り試験時の応力ひ ずみ線図に解析がフィットするように決定し， $f_{0}==0.37$ とした。また，通常の Gurson モデルでは，fの増加には ボイドの体積膨張とボイドの生成を考えるが，本解析では ゴム変成エポキシ樹脂のゴム粒子数が増加するわけでは無 いのでボイドの生成は無いものとした。 $f_{0}=0.37$ という值
表 2 損傷解析に用いたゴム変成エポキシ樹脂の材料定数

\begin{tabular}{cccccc}
\hline $\begin{array}{c}E \\
(\mathrm{GPa})\end{array}$ & $\nu$ & $\begin{array}{c}\sigma_{\mathrm{Y}} \\
(\mathrm{MPa})\end{array}$ & $\begin{array}{c}\sigma_{0} \\
(\mathrm{MPa})\end{array}$ & $f_{0}$ & $\begin{array}{c}G_{\mathrm{C}} \\
(\mathrm{N} / \mathrm{m})\end{array}$ \\
\hline 2.54 & 0.37 & 42.1 & 68.0 & 0.37 & 440 \\
\hline
\end{tabular}

は，明らかにゴム粒子の体積含有率よりも大きい。ここで は, $f_{0}$ の值は現実のボイド率というよりも，降伏関数のフィッ ティングパラメータとして取り扱った。最終的に求めた物 性值を表 2 に示す。

\section{2 接着層の簡易解析モデル}

有限要素法解析にあたっては, 計算時間を節約し, き裂 先端付近の応力分布と損傷分布をより細かな要素分割で解 析するために, 図 4 で示したような, 被着材を剛体とし上 下の剛体被着体に強制変位を与える簡易モデルを用いた。 あらかじめ, 被着材をアルミニウムとした CT 接着継手の き裂先端損傷域の解析を行い, 剛体被着体モデルと比較し たが，接着剤層厚さとエネルギー解放率が同じ場合のき裂 先端の応力ひずみ分布は両者でほぼ等しかったため,この ような簡易モデルでの解析で問題ないと考えた。この簡易 モデルのエネルギー解放率は, 次式より簡単に求められる。

$$
G=\frac{E_{a}\left(1-\nu_{a}\right)}{\left(1+\nu_{a}\right)\left(1-2 \nu_{a}\right)} \frac{\nu_{0}^{2}}{H}
$$

ここで， $E_{a}$ と $\nu_{a}$ は, 接着剤のヤング率とポアソン比であ る。

\section{3 接着剂層中のき裂の破壊䩚性值の推定}

ここでは, 次式で示されるき裂先端の累積損傷率が一定 值に達したときに，き裂が進展すると仮定した。

$$
S=\int_{0}^{l} c\left(f-f_{0}\right) d x
$$

ここで, $S$ は累積損伤率， $l_{c}$ はバルク接着剤におけるき裂 先端前方の損傷域の長さである。このようにして, 推定し た接着継手の破壊靭性值を図 12 にロで示した。この結果 は, 接着剤層厚さの減少に伴って破壊勒性值が徐々に減少 する 4 章での弾塑性解析と同様の傾向を示しており, 今回 


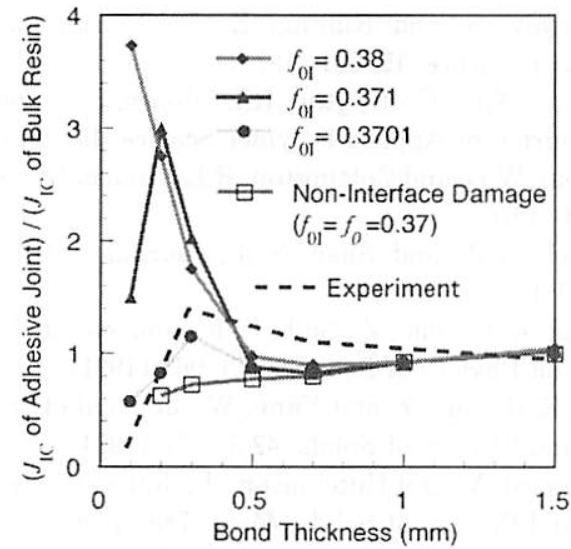

図 12 Gurson モデルを用いて有限要素法解析より 予測した破壊勒性值と実験結果の比較

のゴム变成エポキシ樹脂の傾向を表すものでは無い。すな わち, 被着材の二次元的な拘束効果だけでは, 接着剤層が 薄くなった際の破壊勒性值の減少しか説明できない。

\section{4 界面損傷域の考慮}

5 章に示したとおり，実験による観察では，破壊勒性値 が極大值をとる接着剤層厚さ $0.3 \mathrm{~mm}$ の場合には，接着剤 層之被着材の界面に沿って大規模な損傷域が発達している ことが観察された。この界面損傷域は，おおむね接着剤層 厚さが $0.7 \mathrm{~mm}$ 以下の場合に観察されている。そこで, 上 述の損傷解析においても, 界面損傷域を模擬するために界 面に沿った $0.01 \mathrm{~mm}$ の薄い領域の初期ボイド率を僅かに 他の領域よりあ大きくして解析を行った。図 12 に界面領 域の初期ボイド率 $f_{01}$ を $0.3701 ， 0.371 ， 0.38$ としたときに, 式（24）を用いて推定した破壊勒性值を，図 13 にき裂先端 の損傷域の発達の様子を示した。これより, 界面に沿った 薄い領域の初期ボイド率を僅かに上昇させて解析させただ

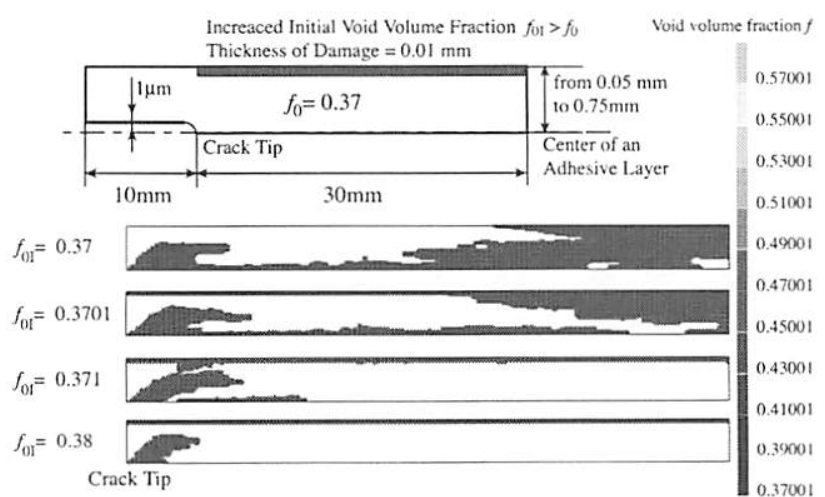

図 13 接着剤層厚さ $0.3 \mathrm{~mm}$ の場合に, 接着剤層之被着材の 界面に沿った $0.01 \mathrm{~mm}$ の領域の Gurson モデルに おける初期ボイド率をわずかに増加させて解析を 行った際の, き裂先端近傍のダメージゾーンの分布 の变化 (わずかな界面損傷がき裂先端の損傷を縮小 させている様子がわかる)。

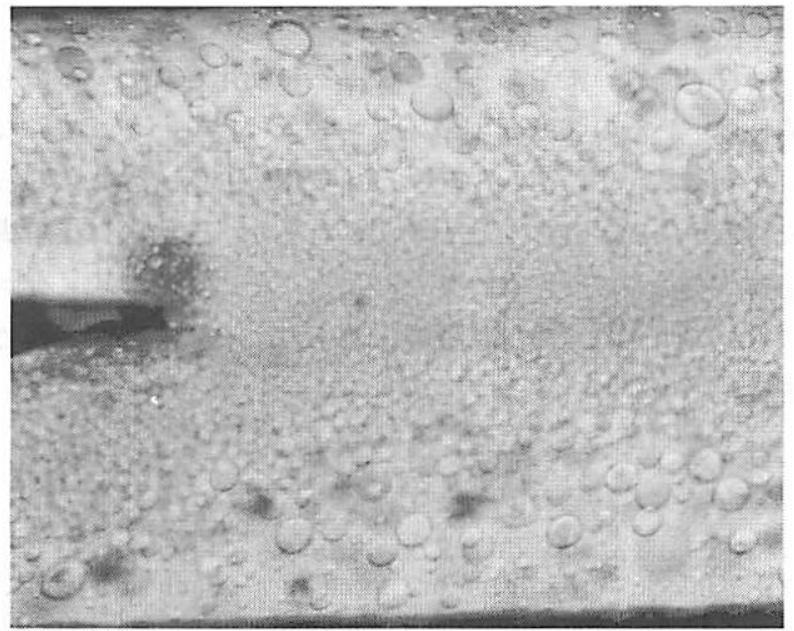

図 14 肥大化したアルミニウムと接着剤層の 界面付近のゴム粒子

けでも実験結果に近い接着剤層厚み依存性が再現されるこ とがわかった。このことは, 界面損傷域の応力遮蔽効果が, ある接着剤層厚みで極大值をとる接着剤層厚み依存性を発 現させているとする実験観察からの推定を補強するものと 考えられる。また，極大值をとらずに接着剤層厚みの減少 に伴って破壊勒性值が減少する接着剤では, この界面損傷 があまり発達していないものと予測される。

\section{5 界面損傷を発生させるメカニズム}

界面損傷域の応力遮蔽効果が特定の接着剤層厚さでの破 壊勒性值の極大值を与えているとしても，なぜ界面損傷域 が発生するのであろうか。

その一つの理由として, 図 14 に示すように界面付近の ゴム粒子の直径が他の部分よりあ数倍から十倍程度大きい ことが挙げられる。本研究で用いたゴム変成エポキシ樹脂 は，液状ゴム $(\mathrm{CTBN})$ を用い，エポキシ硬化時のゴムの 析出を利用してゴム粒子を分散させている。アルミニウム とエポキシ樹脂および液状ゴムとの親和性の違いは，アル ミニウムが界面にエポキシ樹脂を引き寄せ，わずかに界面 から離れた領域にゴム粒子が移動する際にゴム粒子の合体 が生じ，この付近のゴム粒子を肥大化させていると考えら

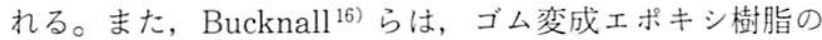
キャビテーション発生モデルにおいて，より大きなゴム粒 子の方がキャビテーションを発生しやすいことを示してい る。

\section{7. おわりに}

接着継手の破壊靶性について, 破壊力学的試験法と接着 剤層厚みがエネルギー解放率に与える影響について解説し た。さらに接着剤の破壊䩲性值そのものが接着風層厚みの 影響を受ける場合があることを示し，そのメカニズムにつ いて実験・解析の両面からのアプローチによって考察した 
例を紹介した。

接着剤は，いまやあらゆるところに使用されているにも 関わらず，その強度発現のメカニズムは良くわかっていな い。今後, 接着構造は, ますます他の機械的締結法に代わっ て利用されるようになると予測されるが，その際に接着構 造物が安心して使用されるためには，その強度発現メカ二 ズムが解明され，設計に取り入れられていくことが必要で ある。

\section{参 考 文 献}

1）岡村弘之, 線形破壊力学入門, 培風館, (1976).

2) Kinlock, A. J., "Fracture mechanics of adhesive joints," Adhesion and adhesives," Chapman and Hall, 264 (1987).

3) Andrews, E. H. and Stevenson, A., Journal of Materials Science, 13, 1680 (1978).

4) Ikeda, T., Yamashita, A., Lee, D. and Miyazaki N., Transaction of ASME, Journal of Engineering Materials and Technology, 122, 80 (2000).

5) Gardon, J. L., Journal of Applied Polymer Science, 7, 625 (1963).
6) Mostovoy, S. and Ripling, E. J., Journal of Applied Polymer Science, 15, 661 (1971).

7) Bascom, W.D., Cottington, R.L., Jones, R.L. and Peyser, P., Journal of Applied Polymer Science, 19, 2545 (1975).

8) Bascom, W.D. and Cottington, R.L., Journal of Adhesion, 7, 333 (1976)

9) Kinloch, A. J. and Shaw, S. J., Journal of Adhesion, 12, 59 (1981).

10) Varias, A. G., Suo, Z., Shih, C. F., Journal of the Mechanics and Physics of Solids, 39(7), 963 (1991).

11) Hsia, K. J., Suo, Z. and Yang, W., Journal of the Mechanics and Physics of Solids, 42(6), 877 (1994).

12) Tvergaard, V. and Hutchinson, J., Journal of the Mechanics and Physics of Solids, 44(5), 789 (1996).

13) Lee, D., Ikeda, T., Miyazaki, N. and Choi, N. S., Journal of Materials Science Letters, 22, 229 (2003).

14) Lee, D., Ikeda, T., Miyazaki, N. and Choi, N. S., Trans. ASME, Journal of Engineering Materials and Technology, 126, 14 (2004).

15）池田徹，李徳甫，宮崎則幸， 日本接着学会誌，42(3)，97 (2006).

16) Bucknall, C. B., Karpodinis, A. and Zhang, X.C., Journal of Materials Sciences, 29, 3377 (1994). 